\title{
A CONCEPÇÃO MAQUIAVELIANA DE NECESSIDADE POLÍTICA*
}

\author{
José Luiz Ames** \\ profuni2000@yahoo.com.br
}

RESUMO Poucos conceitos na obra de Maquiavel se repetem com tanta insistência quanto o de necessità - e os termos correlatos como necessario(e), necessitato(i) etc. - obrigando-nos a reconhecer nele uma categoria de especial significação. Trata-se, sem dúvida, de um conceito que, na obra do florentino, abarca um espectro muito amplo de sentidos diversos, que vão desde o mais usual ao mais teórico e político. O presente estudo procurará distinguir esses diferentes usos que Maquiavel faz do termo, particularmente nas obras "O Príncipe" e "Discursos sobre a primeira década de Tito Livio", antecedendo-o de uma analise crítica acerca da maneira segundo a qual a tradição interpretou o significado de necessità na obra de Maquiavel.

Palavras-chave Maquiavel, Necessidade, Liberdade, Ação política, Fortuna.

ABSTRACT Few concepts in Machiavelli's work are so insistently repeated as the concept of necessità - as well as its correlated terms such as necessario(e), necessitato(i), etc. -, forcing us into the acknowledging in his work a category of special significance. It is undoubtedly a concept that embraces, in his work, a very wide spectrum of diverse senses, which come from the most common up to the most theoretical and political of those senses. The present investigation will try to distinguish such different uses of the term, as used by Machiavelli,

* O presente trabalho integra projeto de pesquisa financiado pelo CNPq com a concessão de bolsa em produtividade. Artigo submetido em 30/06/2017. Aceito em 02/10/2017.

** Unioeste - Universidade Estadual do Oeste do Paraná, Cascavel, Paraná, Brasil. 
particularly in the works "The Prince" and "Discourses on the First Ten Books of Titus Livy", preceded by a critical analysis on the way by which tradition has interpreted the meaning of necessità in Machiavelli's work.

Keywords Machiavelli, Necessity, Freedom, Political Action, Fortune.

Poucos conceitos na obra de Maquiavel se repetem com tanta insistência quanto o de necessità ${ }^{1}$ - e os termos correlatos como necessario(e), necessitato(i) etc. - obrigando-nos a reconhecer nele uma categoria de especial significação. Trata-se, sem dúvida, de um conceito que abarca um espectro muito amplo de sentidos diversos, que vão desde o mais usual ao mais teórico e político. Nosso esforço no presente estudo será o de caracterizar e distinguir esses diferentes usos que Maquiavel faz do termo. Pretendemos mostrar, a partir de um estudo analítico, que o propósito de Maquiavel é indicar de que maneira é possível colher a necessità própria aos tempos conservando o libero arbitrio que torna o homem responsável único pela ação histórica. Antes, porém, de entregar-nos a essa tarefa analítica, vamos situar, ainda que de modo conciso, a maneira segundo a qual a tradição crítica interpretou o significado de necessità na obra de Maquiavel.

\section{Necessità na tradição interpretativa da obra de Maquiavel}

$\mathrm{Na}$ tradição filosófica ocidental, o termo latino necessitas expressa tanto o sentido de constrição derivada de uma falta ou ausência quanto a constrição devida ao fato de estar vinculada a contextos e causas determinadas que, frequentemente, assumem a natureza do inevitável, daquilo que não pode ser de outro modo. Dessa maneira, a discussão sobre o papel da necessidade se torna, muitas vezes, um modo de examinar questões de responsabilidade ética ou política: até que ponto os agentes devem ser elogiados ou culpados por aquilo que fazem sob a constrição da necessidade? Esse sentido, sem dúvida, influencia a concepção maquiaveliana, embora não esgote o inteiro de sua compreensão, como mostraremos mais adiante. Podemos dividir as diferentes interpretações

1 O termo necessità ocorre 229 vezes na obra de Maquiavel, ao passo que necessario ocorre 248 vezes Somando todos os termos correlatos à necessità, podem ser contabilizadas 667 ocorrências na obra de Maquiavel, frequência menor apenas ao do termo stato(i). 
acerca da concepção maquiaveliana de necessidade em três grupos principais: (a) determinista; (b) hipotético; (c) ético-político.

\section{a) Interpretações deterministas}

Felix Gilbert ressalta que nas "Pratiche fiorentine", particularmente nos relatórios das sessões dos principais órgãos do governo da cidade, se falava de necessità "quando a acumulação de circunstâncias adversas era tão grande a ponto de não deixar mais escolha: necessidade 'não tem lei', 'necessidade obriga' [diziam]. A necessità, portanto, reduz os cálculos humanos a reações automáticas" (Gilbert, 1977, p. 96).

Esse sentido determinista de necessità que Gilbert identifica nas "Pratiche" encontra eco na interpretação que Friedrich Meinecke faz do uso desse termo por Maquiavel. Com efeito, para Meinecke (1929, pp. 46-47),

virtù e necessità mantêm em Maquiavel uma relação semelhante a que mantêm na Filosofia moderna a esfera dos valores e a esfera da causalidade [Kausalzusammenhanges], a qual fornece os meios e as possibilidades para a realização dos valores. Se virtù era a forma de vida dos homens que criava e mantinha os Estados, dando-lhes sentido e significação, então necessità era a constrição causal (kausale Zwang), o meio para dar à massa inerte a forma requerida pela virtù.

A necessidade, continua Meinecke $(1929$, p. 50) um pouco mais adiante, é o "mecanismo causal" (kausale mechanismus) das ações. A interpretação proposta por Meinecke leva-nos a interrogar: até que ponto Maquiavel compreende efetivamente necessità como "constrição causal" ou "mecanismo causal" das ações? O exame de algumas passagens da obra de Maquiavel parece indicar que não se trata de necessidades causais, de causas inevitáveis que produzem uma ação inevitável. Assim, por exemplo, quando Maquiavel afirma: "se um príncipe quiser manter-se no poder, então é necessário que aprenda a não ser bom e sê-lo e não o ser conforme a necessità" ("O Príncipe", XV:6, grifos meus). ${ }^{2}$ Nos "Discursos" (III,41:5 - grifos meus): "se se delibera sobre a salvação da pátria, então não se deve fazer consideração alguma sobre o que é justo ou injusto, piedoso ou cruel, louvável ou ignominioso"' Volendosi mantenere escreve Maquiavel: se o príncipe quer, então deve agir dessa ou

2 Citaremos "O Príncipe" a partir da edição bilíngue publicada pela editora Hedra (São Paulo, 2009), cuja tradução e notas (de José Antônio Martins) foi feita a partir da edição crítica de Giorgio Inglese, indicando o capítulo e a linha respectiva. Cotejaremos a tradução oferecida com o próprio texto original da edição citada e introduziremos modificações pontuais sempre que considerarmos que a tradução oferecida poderia ser melhorada.

3 Citaremos os Discursos sobre a primeira década de Tito Livio pela edição crítica estabelecida por Giorgio Inglese (Milano: Rizzoli Editore, 2000) indicando nas passagens citadas o livro, o capítulo e a linha. 
daquela maneira; ou seja, o príncipe não está determinado de forma causal a agir inevitavelmente de uma maneira única. $\mathrm{O}$ mesmo vale para a passagem referida dos Discursos: apenas aquele que cogita acerca da salvação da pátria está lançado numa situação na qual determinada ação se configura como a única adequada; no entanto, também aqui não rege um "mecanismo causal", mas antes a vontade que "delibera".

\section{b) Interpretações hipotéticas}

Leonard von Muralt, contrapondo-se à posição de Meinecke, argumenta que Maquiavel não utiliza o conceito de necessità em um sentido determinista. Antes, situações precisas de necessidade exigem ações bem determinadas. Nessas situações, a necessidade é "provocada" voluntariamente, se apoia sobre decisões determinadas em vista da consecução de um objetivo determinado. O efeito das decisões sobre os homens pode ser a de uma "constrição causal", como Meinecke defende, mas as decisões não são, por si mesmas, uma "constrição causal". Essa restrição leva Leonard von Muralt (1945, p. 54) a concluir: "necessità é para Maquiavel em geral algo condicionado, e não incondicionado, como é entendida, ao que parece, na interpretação de Meinecke". Enfim, não é uma "constrição causal”, não é uma necessidade inevitável, e sim uma necessidade condicionada.

Gérard Collona d'Istria e Roland Frapet (1980, p. 62) endossam igualmente essa recusa da interpretação determinista de necessità em Maquiavel proposta por Meinecke: "Maquiavel utiliza frequentemente o termo necessário. O termo não significa necessidade absoluta, mas indica a direção na qual se engajar, ou a atitude a tomar, considerando as circunstâncias, se se quiser ter êxito ou se manter". Para esses intérpretes, Maquiavel costuma enunciar como máximas (precetti) de dever-ser as regras de ação orientadas pela necessidade; ou seja, as escolhas essenciais são formuladas como alternativas em que o indivíduo é, de alguma maneira, obrigado a aceitar um dos termos porque o outro aparece como ruinoso, como uma via sem saída e impossível de utilizar. Isso, ressaltam, mostra que o

dever-ser em Maquiavel deve coincidir com a necessidade, que se deve querer o que é necessário. Neste mundo de Maquiavel, não é o livre-arbítrio que conduz os homens, é a necessidade. Ou antes, o livre-arbítrio consiste em querer a necessidade, em compreendê-la e reapoderar-se dela ativamente, não em sofrê-la, mas em querê-la: tu deves fazer isto, porque tu não podes agir diferentemente (Collona D'Istria; Frapet, 1980, pp. 61-62).

Mostra-se aqui que o imperativo da ação não é de natureza moral: deve-se agir ou não agir de determinada forma não porque a ação está subordinada a 
determinadas obrigações morais, e sim porque está condicionada pelo resultado, pela necessidade de alcançar determinado objetivo político. Evidencia-se também, com isso, que o caráter de obrigação implicado na ação não é absoluto, e sim hipotético, tal como já o havia ressaltado von Muralt em sua crítica a Meinecke. Compreendemos, então, que o sujeito está confrontado, nas situações históricas concretas, a um quadro de escolhas que se reveste da forma de um dilema que exige sempre a opção por um dos termos, uma vez que o outro aparece como danoso, como uma via sem saída, ou como portador de resultados opostos aos visados.

A estrutura desse dilema imposto pela necessidade pode ser resumida ao seguinte esquema, conforme Wolfgang Kersting (1988, pp. 246-247): as situações históricas $\mathrm{x}, \mathrm{y}, \mathrm{z}$..., suficientemente comparáveis entre si com base em suas características comuns, revelam que alguém que visa um fim " $\mathrm{f}$ " deve, obrigatoriamente, realizar a ação "a”, se quiser alcançar a meta almejada. Quer dizer, se alguém persegue - ou pretende perseguir - um objetivo idêntico ou semelhante a "f", e se ele se encontra numa situação suficientemente análoga a x, y ou z, é razoável somente se executar uma ação do tipo "a"; ou ainda, se alguém persegue um resultado idêntico ou semelhante a " $\mathrm{f}$ ", mas que se encontra numa situação que não se assemelha a $\mathrm{x}, \mathrm{y}$ ou $\mathrm{z}$, deve modificar de tal modo sua situação que essa se assemelhe a x, y ou z para, mais tarde, executar a ação exitosa do tipo "a", ou então procurar por uma estratégia de êxito nova dirigida para a situação encontrada. Essa estrutura das regras, ou máximas, argumenta Kersting (1988, p. 246),

assegura o contexto e a concatenação dos eventos singulares e possibilita desse modo a
aplicabilidade da estratégia do êxito da análise histórica unicamente porque a história é
dominada pela necessidade e não se despedaça em particularidades isoladas. Graças a
isso podem ser extraídas regras a partir da observação da história que elevam nosso saber
político acerca dos meios e sua disponibilidade, o que torna o comportamento humano
mais calculável tornando mais promissora a expectativa de êxito, reduzindo o risco
da desilusão e ajudando a evitar as interferências incômodas na realização das ações.

Sebastian de Grazia (1993, p. 207) aproxima sua interpretação da necessità maquiaveliana à exposta por Kersting: "a necessidade pode caracterizar um curso de ação ditado pela busca de um ideal ou objetivo", afirma ele. Essa acepção, prossegue, aparece numa espécie de raciocínio silogístico: "para ir de A a C, é preciso passar por B. Para ir de A (um mau costume) a C (um bom costume), B (a lei) é “imediatamente necessário"” (De Grazia, 1993, p. 207). Assim compreendida, a necessidade se revela uma limitação para a ação. Ainda que as alternativas não desapareçam, ficam anuladas em sua viabilidade prática pela imposição das circunstâncias. "Os homens reconhecem a necessidade 
quando preferem um curso de ação que supõe uma ordem contrária à ordem existente, ou seja, uma impossibilidade natural", afirma De Grazia (1993, p. 207). Considerando a propensão malévola dos homens, a escolha, em geral, leva-os a uma ação má. Assim, se a necessidade os obriga a determinada ação, "aumenta, em vez de diminuir, a possibilidade de uma ação política virtuosa", conclui De Grazia (1993, p. 209).

Uma interpretação próxima, mas que em alguns aspectos se singulariza, pode ser encontrada em Lanfranco Mossini. Segundo o pensador italiano, experiência, história e natureza representam, aos olhos de Maquiavel, algo de perfeito e exemplar precisamente porque nelas domina a necessidade; ou seja, porque nelas o ser não é algo diferente do dever-ser, o como se vive não diverge do como se deveria viver.

Se tudo isso também se verificasse no homem, se também no mundo do homem imperasse soberana a ordem da natureza, sem qualquer falha, sem espaços vazios, sem exceções, se instintivamente o homem fosse levado à vida social e política e à conexa prática da justiça, à vontade do bem comum antes do que à inteiramente egoísta do particular, não existiria então, sequer para o homem, qualquer necessidade de virtù e sabedoria política, com todos os seus institutos e princípios, suas cruas exigências e limitações (Mossini, 1962, p. 42).

No entanto, afirma Mossini, constata-se, no mundo do homem, uma cisão entre necessidade e virtù. Essa separação, argumenta ele, não pode acontecer, a menos que "intervenha algum fator de perturbação e corrupção, a menos que seja descoberta a existência de algo que tenha em si a possibilidade e a força de se opor ao curso da necessidade natural" (Mossini, 1962, p. 43). O que possui essa "força", qual seria esse "fator perturbador"? Para Mossini (1962, p. 47), Maquiavel atribui isso à elezione. Se no homem não existisse, ou pudesse ser freada, a licença da elezione, argumenta Mossini, imperaria a ininterrupta regularidade e necessidade que são possíveis de vislumbrar sob a multiplicidade e dinamicidade da experiência e da história. Contudo, em vez disso, "a lei da natureza, a racionalidade da história, $[. .$.$] a virtù da necessidade permanecem$ [...] sufocadas pela desordem das paixões" (Mossini, 1962, p. 47).

Vemos que, segundo Mossini, o homem maquiaveliano é concebido como parte - momento - da universal e imutável ordem da natureza, submetido às suas regras e exigências, concebido como capaz de perfeição enquanto governado pela necessità. Também à vida e à atividade humanas é extensível a lógica interna que rege a necessidade, não por um procedimento analógico, mas porque a matéria é a mesma uma vez que, segundo Maquiavel, "todas as ações nossas imitam a natureza" ("Discursos" II,3:12). Assim, Mossini parte, em sua interpretação da necessità maquiaveliana, da ideia de natureza como 
perfeita: quem quer que a imite não pode ser censurado, pois nela reina a absoluta necessità. Precisamente, por isso, o homem, enquanto refém da elezione, livre para fazer o que querem as paixões, se distancia da ordem e da racionalidade naturais, as quais se transformam agora de um fenômeno objetivamente dado em uma tarefa e um problema. Nas palavras de Mossini (1962, p. 51), a ordem e a racionalidade próprias à natureza - que caracterizam também o homem enquanto comandado pela necessità - transformam-se, por assim dizer, "quando o empreendimento político é coroado de êxito, em uma necessità de segundo grau, que torna a se confundir sem mais com a originária e imutável necessidade da natureza, mas somente por meio do esforço de uma vontade, a tensão e aplicação de uma contínua iniciativa e virtù". Agora a lei da necessidade não é mais uma só coisa com sua concreta aplicação. Em vez disso, "por meio da virtù política, a necessità precisa ser reconquistada contra a desordem das paixões, da elezione" (Mossini, 1962, p. 51). Numa frase: a elezione torna a "lei da necessidade" sem efeito; para corrigir a inevitável desordem que resulta disso, emerge a "necessidade da lei", isto é, a virtù política capaz de regular as coisas segundo a ordem natural.

\section{c) Interpretações ético-políticas}

Para completarmos, esse quadro interpretativo da concepção maquiaveliana de necessità e avançar para o esforço analítico desse conceito a partir da obra mesma de Maquiavel, cabe mencionar a interpretação de dois pensadores que interpretam necessità como constrição fundadora do agir moral para Maquiavel. Assim, para José Sánchez-Parga o conceito de necessidade, em Maquiavel, "inaugura, expressa e funda uma ética da responsabilidade política" (SánchezParga, 2005, p. 274). O argumento de Sánchez-Parga é o seguinte: o conceito de necessità expressa o grau de responsabilidade política que força o sujeito a uma determinada ação; por conseguinte, o sujeito político, forçado pela responsabilidade de sua ação, dos fins e resultados dela, se encontra desculpado de suas outras responsabilidades (religiosas, morais, legais etc.) em virtude dos meios empregados.

Sánchez-Parga alerta a respeito do "realismo ingênuo", no qual, segundo ele, a necessità é reduzida ao conjunto de condições e fatores que externamente obrigam à ação e, à margem dela, co-agem e forçam o sujeito político a agir de uma determinada maneira. Em oposição a essa interpretação, Sánchez-Parga defende que a necessità maquiaveliana se impõe à ação desde sua própria obra e resultados enquanto fim da própria ação que a co-ata como algo necessário, responsabilizando o sujeito político dela. Interpretar a necessità em Maquiavel como razão ou força que suspende qualquer outra normatividade é ignorar que 
a necessidade é também produto das leis e instituições que obrigam os homens a agir responsavelmente de acordo com elas, critica Sánchez-Parga. Por outro lado, "pensada como inerente à ação e às suas próprias obras, a necessidade se converte em um princípio tão fundamental quanto permanente de toda atividade política: a que define a responsabilidade do sujeito político em todos os momentos e em tudo o que faz", conclui Sánchez-Parga (2005, p. 275).

Na mesma perspectiva, Erica Benner (2009, p. 135) opõe-se à interpretação daqueles que associam necessità "aos limites objetivos sobre a escolha moral"; isto é, de que "ali onde a necessità entra em jogo, restrições éticas convencionais devem estar subordinadas às necessidades objetivas de auto-preservação". Em oposição a essa leitura, argumenta que esse tipo de posição é, na verdade, uma "retórica justificatória" do conceito de necessità. Segundo esse uso, "se um agente teve muito pouco espaço para a escolha não pode ser considerado totalmente responsável pelas consequências de suas ações” (Benner, 2009, p. 136). Para essa intérprete, "Maquiavel questiona tais usos irresponsáveis da palavra necessità", uma vez que mesmo pessoas que agem sob forte coação "podem escolher entre diferentes cursos de ação pelos quais devem ser responsabilizados" (Benner, 2009, p. 138-139). Cita como exemplos de um agir moralmente responsável, mesmo sob forte coação externa, os feitos de Moisés e de Enéias: ambos mostram sua virtude exercendo a margem muito estreita de liberdade que lhes é dada e aceitando as limitações da derrota ou escravidão passadas como condições para suas próprias escolhas. Assim, defende Benner (2009, p. 146),

mesmo sob constrições extremas os agentes devem escolher entre as diferentes formas de dar resposta à situação; eles podem, de fato devem, ser responsáveis por suas escolhas. No mínimo, podem optar por fugir ou ficar e lutar. E então devem escolher a forma de fugir ou de lutar: atacando de uma forma feroz, e refletida, ou por "ordem" a si mesmos para sua futura segurança. Uma vez que estas opções estão sempre disponíveis, mesmo sob uma "necessidade fundamental", há sempre espaço para o louvor ou a crítica.

\section{Características gerais da concepção maquiaveliana de necessità}

O conceito de necessità se forma progressivamente na mente de Maquiavel. Fabio Raimondi (2009, pp. 32-38) mostra a lenta maturação dessa noção na obra do florentino por meio do exame dos escritos produzidos durante os anos em que esteve a serviço da república de Florença. Raimondi ressalta que, nesses escritos, se fala de necessità não somente ali onde o termo aparece explicitamente, mas também lá onde a linguagem se exprime segundo a peremptoriedade própria ao termo necessità. No presente estudo, não nos ocuparemos da formação do conceito em Maquiavel, detendo-nos unicamente sobre dois textos da "maturidade", "O Príncipe" e "Discursos". 
Que necessidade é essa à qual o homem consegue tão frequentemente se subtrair nas suas ações? Para compreender essa ideia paradoxal do pensamento maquiaveliano é preciso ter presente que em sua obra o conceito de "natureza" oscila quase continuamente entre duas acepções diferentes e quase opostas: por um lado, a natureza como um conceito universal, como a ordem das coisas que rege internamente tudo quando há no cosmo e, por conseguinte, também o curso da vida humana; por outro lado, se faz presente uma acepção de natureza vinculada à elezione que se cinde e destaca da estrutura e das leis universais da natureza cósmica. Essa segunda "natureza" também tem sua ordem e suas leis, não necessariamente coincidentes com aquelas da natureza universal, fundadas tanto sobre a elezione e o livre arbítrio, quanto sobre a necessità. Assim, impera sobre o homem uma dupla ordem natural: a universal e a particular. Nessa segunda opera, aquilo que Mossini (1962, p. 70) definiu como "necessidade de segundo grau", que não exerce sobre o homem a mesma força coativa da "necessidade de primeiro grau" da ordem natural universal, porque sofre a influência da elezione e do livre arbítrio.

O pensamento maquiaveliano está, pois, atravessado por essa tensão: de um lado, a determinação das forças naturais que fazem ressaltar a impotência humana diante do curso natural das coisas; de outro lado, a possibilidade de espaços para a livre ação dos homens graças à elezione. No entanto, o êxito da livre ação humana está condicionado a encontrar, no interior do contínuo fluir natural das coisas, pontos firmes, sob a forma de leis, que coloquem o homem político em condições de agir apelando tanto à consciência da existência de forças constritivas naturais, quanto a sua livre capacidade de interpretar as situações e determinar os meios de controlá-las pela identificação das regularidades leis - nelas presentes.

É esse confronto entre necessidade e liberdade que se faz presente na obra de Maquiavel e que fazem do stato libero uma obra que, por um lado, pressupõe a necessidade natural, mas de outro exige a virtù de homens que agem por elezione. O problema com o qual Maquiavel se defronta pode ser assim resumido: como reconduzir o homem àquilo que ele deve ser (isto é, de ser função orgânica da natureza, de ser comandado pela necessità) partindo daquilo que é (ou seja, alguém afetado pelas paixões e pela capacidade da elezione, alguém que se orienta pelo livre arbítrio)?

$\mathrm{O}$ problema assim formulado permite compreender que entre natureza e paixões humanas existe choque, fricção e luta e, por conseguinte, que é inevitável que esse conflito exista igualmente entre os próprios homens. Se é necessário (quer dizer, se é expressão natural), esse conflito tem regularidades, isto é, leis que Maquiavel procura colher na sua necessidade a partir do contingente. $\mathrm{O}$ 
que estabelece a junção entre natureza (e sua necessidade) e homens (com suas paixões) é a razão: a aparente casualidade do curso natural das coisas revela leis estáveis que subtendem ao curso natural e regulam o seu andamento. Aquele que souber identificar essas leis conformando a elas sua ação alcança êxito com muito maior probabilidade. É o que Maquiavel designa por virtù: não a capacidade de enfrentar e submeter a fortuna (o aleatório e casual não têm como ser submetido), e sim o talento de captar as regularidades - ou "leis" que subjazem ao aparentemente casual dos acontecimentos e orientar sua ação no sentido dessas.

Para Maquiavel, portanto, a capacidade de dominar a necessità não revela uma ação de virtù. Responder a qualquer necessità pelo confronto e oposição firme, como se a "superação" ou "controle" da necessidade revelasse virtù, é uma ideia equivocada. Agentes de virtù, para Maquiavel, são os que, primeiro, revelam-se capazes de distinguir entre as diferentes modalidades de aparecer da necessidade e, segundo, elaboram formas adequadas de determinação de resposta a ela. Vejamos essa questão um pouco mais detalhadamente.

Maquiavel emprega o termo necessità para designar constrições que se originam de diferentes fontes. Assim, podemos identificar três modalidades distintas de aparecimento da necessidade. Primeiro, podem ser constrições naturais como as características físicas do local que se oferecem no momento da fundação, como também catástrofes naturais como fomes, pestes, inundações ou calamidades em geral. Segundo necessità podem ser as constrições atribuídas a agentes que escapam ao controle da vontade humana, como a fortuna, os céus e a natureza. Terceiro, necessidade pode ainda referir-se ao conjunto de constrições produzidas pelos próprios homens, as quais incluem desde as pressões históricas, econômicas e políticas que motivam os povos a construir novas cidades ou a promover guerras de conquista, como certos desejos e umori "comuns e naturais" que agitam todas as cidades: os tumultos resultantes dos humores opostos daqueles que desejam dominar e os que desejam não ser dominados ("Discursos" I,4-5; Príncipe IX). Desse terceiro grupo, surge a "necessidade artificial" da lei positiva que regula a ação dos homens na vida política.

$\mathrm{O}$ agente de virtù se diferencia pelo modo como enfrenta essas diferentes formas de constrição impostas pelas distintas modalidades com que aparece a necessidade. Primeiramente, aceita as constrições existentes como condições para ações futuras. É a situação que Maquiavel ilustra no primeiro capítulo dos "Discursos": a obra de fundação se defronta com constrições preexistentes (ou lugares estéreis ou lugares férteis) que precisam ser levadas em consideração para assegurar o bom êxito da obra. É igualmente o que Maquiavel ilustra no capítulo VI de "O Príncipe": Moisés, Ciro, Rômulo e Teseu, cada um à sua 
maneira, fizeram das condições adversas preexistentes o ponto de apoio para a sua obra fundadora.

Em segundo lugar, homens de virtù não apenas aceitam as constrições preexistentes, quanto também criam voluntariamente novas constrições (necessidades) para servir aos seus propósitos. No mencionado capítulo inicial dos "Discursos", isso corresponde à criação de leggi et ordini que se impõem aos homens com a força constritiva da necessidade a fim de regular o seu comportamento. A invenção de necessidade é ilustrada ainda por Maquiavel no capítulo 12 do terceiro Livro dos "Discursos" por um outro modo que não a da lei positiva: a ação dos capitães na guerra. Eles apelavam à invenção da necessidade de duas maneiras distintas, mas complementares, segundo Maquiavel: por meio da imposição de novas necessidades aos seus próprios homens para torná-los mais obstinados; pela remoção da necessidade imposta aos seus inimigos para torná-los menos ferozes. Assim, capitães antigos "faziam de tudo para que os seus soldados fossem premidos pela necessidade" de lutar de forma disciplinada e de forma altamente motivada. Ao mesmo tempo, "usavam de todas as astúcias de modo que os inimigos se vissem livres" da necessidade para arefecer seu ímpeto na batalha ("Discursos", III,12:3). Assim, saber quando e como "inventar" a necessidade para as próprias tropas e "remover" a necessidade imposta aos inimigos se torna um elemento importante da virtù maquiaveliana. Homens de virtù não só sabem avaliar como e quando impor a necessidade a si mesmos e aos que estão sob seu comando, quanto também como e quando "remover" a necessidade imposta aos adversários.

Finalmente, agentes de virtù enfrentam as constrições "comuns e naturais" com as quais se deparam cotidianamente com a mesma seriedade com que encaram as necessidades que surgem em situações extraordinárias. O desejo de dominar oposto ao de não ser dominado está entre as ações de constrição ordinária - no sentido de ser constitutiva da vida política - que atua de forma mais premente sobre aqueles que têm o encargo de governar. Desejos e humores "comuns e naturais", como esses, nunca têm como ser completamente eliminados. Simplesmente compõem a vida social das cidades e, por isso, requerem regulação contínua. Maquiavel argumenta que as ordens republicanas em Roma foram baseadas no reconhecimento de que a maioria dos tumulti eram "naturais e comuns" por resultarem dos dois principais humores opostos encontrados em todas as cidades. Os ordenadores romanos mostraram sua virtù por preservar e regulamentar esses humores, em dar-lhes sfogo, em vez de tentar reprimi-los. As instituições romanas mostraram virtù por aceitar os diferentes humores como uma necessidade "natural e comum" em qualquer cidade e dando-lhes espaço para "desafogar" (sfogare). 


\section{Acepções de necessità em "O Príncipe" e "Discursos"}

A exposição feita até aqui deixa clara a importância do conceito de necessità no quadro teórico de Maquiavel. Procederemos agora ao estudo analítico desse conceito nas duas obras nas quais esse conceito ocorre mais frequentemente: " $\mathrm{O}$ Príncipe" e "Discursos". Já dissemos anteriormente que o termo necessidade ocorre mais de seiscentas vezes na obra de Maquiavel. O desafio ao qual nos entregamos é o de identificar as acepções dominantes nos usos que o florentino faz do termo e as agrupamos em cinco principais. Não temos a pretensão de, com isso, haver esgotado todos os significados possíveis que termo toma na sua obra, embora as consideremos as mais frequentes.

\section{a) Necessidade como força natural em geral}

Uma primeira acepção de necessità possível de ser destacada das obras mencionadas é a de compreendê-la como o conjunto de leis inalteráveis inerentes ao mundo natural no seu todo, incluído nele os homens. A necessità é, nesse sentido, uma força que comanda a natureza no seu todo. Toda ação tem seu lugar e se conduz segundo as leis e exigências da natureza. Não seria, porém, exato sustentar que esse conceito de uma rigorosa lei de necessidade inerente à natureza e à história seja sem mais afirmado em toda a sua extensão por Maquiavel. Com efeito, as leis absolutas que presidem à realidade, à ordem das coisas, e que, em si mesmas, deveriam prescindir de qualquer contingência de tempo e ocasião e perdurar sempre as mesmas, encontram-se diante de uma realidade que "está sempre em movimento" ("Discursos" II, Proêmio:8), diante de desejos e paixões que variam sempre, "ainda que não variem os tempos" ("Discursos" II, Proêmio:19), e que são totalmente "insaciáveis" gerando "na mente dos homens um contínuo descontentamento e o fastio das coisas possuídas" ("Discursos" II, Proêmio:21). Dessa maneira, a relatividade, mutabilidade e instabilidade das coisas e dos desejos humanos, sua necessária relação com a ordem e a qualità de 'tempi, tornam-se objeto daquelas mesmas leis absolutas e imutáveis às quais mais pareciam contradizer. É importante ressaltar que aquilo que não muda na história e é realizado sempre do mesmo modo não são as coisas em si mesmas, as ações já concluídas e os fins já alcançados pelos homens, mas somente as leis e as regras por meio das quais é possível alcançar aquelas coisas e fins. Essas coisas e fins, porém, não poderão se realizar efetivamente se à adesão ao exemplo da história não seguir a concreta execução por força da 
ação da virtù que soube colher a ocasião acomodando os termos de seu modo de proceder com as condições dos tempos.

Nota-se, pois, que Maquiavel não afirma que o conteúdo, o processo do vir-aser histórico, seja, como tal (isto é, como realização empírica), absolutamente fixo e invariável, mas que esses atributos, próprios às leis, às relações fundamentais que governam a ordem natural, poderiam tornar-se também próprios a esse mundo, das ações dos homens, se esses conseguissem controlar e superar a força das paixões, o eterno "descontentamento" dos seus desejos e ambições.

Assim, ainda que "o mundo sempre tenha sido de um mesmo modo" ("Discursos" II, Proêmio:12) e que "todas as ações nossas imitem a natureza" ("Discursos" II,3:12), que, portanto, todas as coisas estão sob o império da necessidade natural, inclusive a ação humana, essa última é capaz de elezione, pois está dotada de livre arbítrio fazendo com que não seja possível reduzir a necessidade natural a um determinismo físico absoluto. Dentre as diversas passagens nas quais Maquiavel insiste nisso5, a seguinte é significativa: "O restante deveis fazer vós, Deus não deseja fazer tudo para não tirar o libero arbitrio e a parte daquela glória que nos cabe" ("Principe" 26:13 - grifos nossos).

Essa nota característica da natureza humana, o livre arbítrio, não é algo que se opõe ao movimento necessário do curso natural das coisas. Antes, permite extrair desse o que é mais conveniente para a obtenção dos fins visados. Uma passagem famosa de "O Príncipe" nos permitirá ilustrar isso:

Deveis saber, portanto, que são dois os gêneros de combate: um com as leis, outro com a força. O primeiro é próprio do homem e o segundo dos animais. Mas porque o primeiro muitas vezes não basta, convém recorrer ao segundo. Portanto, a um príncipe é necessário saber bem usar o animal e o homem [...]. Sendo, pois, necessário a um príncipe saber bem usar o animal, deve tomar destes por modelo a raposa e o leão: porque o leão não se defende das armadilhas e a raposa não se defende dos lobos; necessita (bisogna), pois, ser raposa para conhecer as armadilhas e leão para amedrontar os lobos ("Principe", 18, pp. 2-7).

O príncipe precisa participar das duas naturezas, a humana e a animal, e dessa última deve partilhar das naturezas de leão e raposa. Se seguir rigorosamente o curso natural fosse sempre garantia absolutamente segura de êxito, bastaria ao homem adotar a natureza animal, pois essa não é afetada pela elezione. Não é isso, porém, o que Maquiavel sugere: por vezes agir segundo a natureza

5 São inúmeras as passagens nas quais ocorre um emprego de elezione no sentido de livre arbítrio. Confiram-se, por exemplo, as seguintes: "Discursos" I, 3:5 ("mas onde a elezione abunda e se pode usar de licença, tudo se logo se enche de confusão e desordem"); "Príncipe" 13:4 ("mas a sua boa fortuna fez nascer um terceiro fator, a fim de que não colhesse o fruto de sua mala elezione"); "História de Florença" I,39 ("o papa [...] e a rainha Joana de Nápoles [...] faziam por necessidade aquilo que os outros haviam feito por mala elezione"). 
humana (isto é, agir segundo a lei) não basta; nesse caso, é preciso usar da natureza animal (isto é, usar da força). Um primeiro movimento de oposição em relação ao curso natural se impõe ao homem para alcançar êxito: precisa escolher qual natureza seguir, a humana ou a animal. Há, porém, mais outro movimento de oposição: precisa decidir entre seguir a natureza da raposa ou a natureza do leão. A referência à necessidade natural não vai, pois, no sentido de enquadrar a ação numa determinação irresistível segundo regras imutáveis, e sim de oferecer modelos de ação conformes à natureza humana ou animal para a deliberação de seu livre arbítrio. No final das contas, a possibilidade de êxito é tributada à elezione e não à necessità, pois precisa escolher entre a natureza humana e animal e, nessa, entre a natureza de leão e de raposa.

A passagem mencionada leva a compreender que a ação especificamente humana não pode ser reduzida pura e simplesmente a regras constantes. $\mathrm{O}$ fato de o homem estar dotado de livre arbítrio o impede. Além disso, e talvez o mais significativo, é o fato de que o êxito da ação está precisamente em que ela não está subordinada à lógica necessitarista da natureza. A possibilidade do êxito está condicionada à virtù: experiência, sabedoria, prudência, clarividência que se opõem à crua necessità da natureza, seja humana ou animal. A necessità natural, podemos notar, tem o aspecto da inelutabilidade, mas também (no caso da natureza humana) da abertura que possibilita o exercício do livre arbítrio, a elezione. Maquiavel nos mostra que a boa direção das ações humanas não é obtida simplesmente anulando o livre arbítrio e submetendo-as à lógica necessitarista da natureza. Antes, a ação virtuosa consiste na capacidade de colher a racionalidade interna subjacente à ordem natural das coisas adequando o agir a ela. Isso implica "adotar" em cada situação concreta a natureza mais conveniente: humana ou animal, de raposa ou de leão, e não em se deixar conduzir deterministicamente por uma dessas.

\section{b) Necessità como força inerente à natureza do homem}

A necessidade pode se apresentar também como uma força interiorizada na forma dos traços constantes da natureza humana, a qual em geral Maquiavel identifica com fortuna. A necessidade, como traços imutáveis da natureza do homem, pode tanto ser uma força que favorece a vitória quanto a que leva ao fracasso das ações. Tudo depende da existência ou não de uma secreta harmonia entre a natureza da pessoa e o curso dos acontecimentos no qual ela age. $\mathrm{Na}$ linguagem de Maquiavel, entre qualità che era in lui e tempi sui: "Creio, ainda que seja feliz aquele que conforma o seu modo de proceder com as exigências dos tempos (qualità de' tempi); do mesmo modo, creio infeliz aquele cujo proceder diverge dos tempos - tempi sui" ("Príncipe" XXV:11). Isso explica 
porque, continua Maquiavel mais adiante, "dois agindo diferentemente, chegam ao mesmo efeito; e dois agindo de modo igual, um alcança seu fim e o outro não" ("Príncipe" XXV:14). Essa lição retoma quase que literalmente aquela que Maquiavel já havia esboçado numa carta escrita a Giovan B. Soderini em 1506: "feliz é aquele cuja maneira de agir se acomoda aos tempos e, pelo contrário, é infeliz aquele que, com suas ações, diverge do tempo e da ordem das coisas". ${ }^{6}$ Nos "Discursos" (III,9:2-4), o tema retorna em palavras semelhantes:

Já considerei várias vezes que a causa da má e da boa fortuna dos homens vem do ajuste do seu modo de proceder com os tempos: porque se vê que os homens, em suas ações, alguns procedem com ímpeto, outros com cautela e precaução. E como em um e outro destes modos se infringem os termos convenientes, não podendo observar-se o verdadeiro caminho, em um e outro se erra. Contudo, erra menos e tem a fortuna próspera quem, como já disse, ajusta seu modo aos tempos e sempre procede conforme te força a natureza (grifos nossos).

É esse ajuste entre natureza do homem e exigências dos tempos que explica, nota Maquiavel um pouco mais adiante, o fracasso de Pedro Soderini e o êxito do Papa Julio II. Com efeito, Soderini - por natureza humano, paciente e bondoso - prosperou, "ele e sua pátria, enquanto os tempos se conformaram ao seu modo de proceder. Quando, porém, chegaram depois tempos em que era necessário romper com a paciência e a humildade, não soube fazê-lo e, assim, arruinou-se junto com sua pátria" ("Discursos" III,9:13-14). O Papa Júlio, por sua vez, agiu durante todo seu pontificado com ímpeto e fúria; e como esse modo de proceder estava ajustado aos tempos, "teve sucesso em todos os seus empreendimentos. Mas, se sobreviessem outros tempos que exigissem outra índole, necessariamente se arruinaria, porque não teria mudado de modo nem de maneira de agir" ("Discursos" III,9:15-16). O problema reside, pois, na dificuldade de adaptar a natureza humana a circunstâncias sempre mutáveis. A "natureza do homem o força", afirma Maquiavel, a sempre agir de uma mesma maneira, de modo que tem dificuldade de captar o sentido secreto das coisas, a estrutura fundamental do mundo à qual, se quiser obter êxito, o homem deve aderir. Com essa exposição, Maquiavel pretende levar seu leitor a duas conclusões importantes sobre o significado da ação política.

A primeira é de que o ator político flexível - entendido como aquele que se adapta rapidamente às novas situações, sente a aproximação de modificações macroestruturais e imediatamente determina de modo novo seus procedimentos 
- está sempre em vantagem em relação ao ator conformado e preso a estratégias de êxito comprovado. Por ser flexível, o ator pode dispor de um arsenal de meios e métodos amplo e bem articulado. $\mathrm{O}$ ator político inflexível, ao contrário, devido à sua natureza rígida, torna-se refém de suas convicções, o que lhe reduz a disponibilidade de meios e métodos. Quer dizer, a grandeza do ator político não está tanto em imprimir a própria marca na realidade modificando-a a seu favor, mas no conhecimento das regras que comandam a ação e na adequação de seu modo de agir às mesmas.

A segunda conclusão é chamar a atenção ao limite mais profundo daquilo que determina o êxito e a eficácia da ação humana: não está em algo exterior, mas na própria natureza do homem, que resiste à mudança e à necessidade de adequar-se às circunstâncias. Afinal, por que o homem não ajusta sempre seu modo de proceder à qualità de’ tempi? Maquiavel apresenta duas razões: “ou porque não pode desviar-se de sua inclinação natural, ou ainda porque, tendo alguém sempre prosperado caminhando por uma via, não se pode persuadi-lo de que seria bom afastar-se dela" ("Príncipe" XXV:16). ${ }^{7}$ Maquiavel ensina, portanto, que a fortuna pode coincidir com a própria natureza humana, com aquilo que há nesta de rígido, unilateral e imutável. Sendo assim, para ser compreendida, na sua gênese e na sua lógica, a fortuna deve ser reconduzida à raiz profunda da natureza humana, aos traços unilaterais e imutáveis em relação à variação das circunstâncias. Com isso, considerada desde esse ponto de vista, a transcendência da fortuna torna-se uma transcendência interiorizada, isto é, de uma parte do espírito humano em relação a ele mesmo. ${ }^{8}$

\section{c) Necessità como força constringente da ação política}

A ação, por ser da ordem do evento, se extingue foi desenvolvida. Como os efeitos da ação conseguem permanecer, durar? Note-se que sem essa permanência

7 Argumentação praticamente igual é feita por Maquiavel nos "Discursos" (III, 9:17): "são duas as razões pelas quais não podemos mudar as coisas: uma, que não podemos nos opor à inclinação de nossa natureza, e a outra, que se alguém prosperou bastante com um modo de proceder, não é possível persuadi-lo que faria bem proceder de outro modo".

8 A necessidade de adaptar o modo de agir às circunstâncias como condição de êxito já fora afirmada por Maquiavel numa carta dirigida a Giovan Battista Soderini, neto do gonfaloneiro de Florença Pedro Soderini, em 1506 (Cf. "Tutte le opere", carta n. 116). Vê-se um governo ou um homem, escreve ele na carta, chegar ao mesmo resultado por meios variados ou com o mesmo meio chegar a fins diferentes. "Como, por outro lado, os tempos são variados e as ordens das coisas são diversas, [...] é feliz aquele que faz concordar seu modo de proceder com o tempo e, pelo contrário, é infeliz aquele que, com suas ações, diverge do tempo e da ordem das coisas". Assim, continua Maquiavel na carta citada, "quem fosse tão sábio que conhecesse os tempos e a ordem das coisas e se acomodasse a elas, teria sempre boa fortuna, ou se guardaria sempre da má". No entanto, conclui o florentino, "como destes sábios não se encontram, primeiro por terem os homens visão curta e depois por não poderem governar sua natureza, sucede que a fortuna muda e governa aos homens e os mantêm sob seu jugo". Assim, "deve-se nas coisas julgar o fim que elas têm e não os meios com que são feitas". 
não existiria política. A permanência ou continuidade requer a existência de estruturas impessoais. Como essas estruturas se formam? Maquiavel mostra que as leggi et ordini que tornam possíveis o vivero politico - são essas as estruturas impessoais que asseguram sua continuidade e permanência - nascem da ação política. As instituições são como que "concentrações" das ações que, enquanto tais, estão fadadas ao desaparecimento. Assim, em seu nascimento, as instituições respondem a reivindicações negadas. São os diques e canais dos quais Maquiavel fala no capítulo XXV de $O$ Principe: estruturas que organizam a vida política de modo que os conflitos que naturalmente a agitam sejam por elas regulados. As leis e as instituições que estruturam a vida coletiva têm na sua origem a ação política, seja sob um principado ou sob uma república. Um príncipe mantém o controle do poder apenas na medida em que os comandos pessoais se converterem em estruturas impessoais na forma de leis e instituições. Uma república unicamente existe quando se instaura uma vida coletiva politicamente institucionalizada.

Muito embora a ação política esteja no centro das reflexões de Maquiavel, não busca propor dela uma definição. A perspectiva a partir da qual a examina não é a do filósofo, ${ }^{9}$ do pensador que pretende determiná-la e apreendê-la abstratamente em um conceito. Em vez disso, o que ocupa Maquiavel é o problema prático a resolver: a efetivação das possibilidades de ação política. Para isso, desempenha função essencial a ideia de "regra geral", noção que Maquiavel emprega com frequência para indicar a ação adequada às circunstâncias.

A maior parte das regras que Maquiavel menciona em sua obra tem um denominador comum: não indicam mecanismos de ação política cujo êxito seria infalível se fossem aplicados à situação adequada, ou seja, aqueles exigidos pela necessità. Maquiavel não autoriza a ideia de que a oportunidade para a utilização das "regras gerais" seja simples aplicação aos casos concretos, e sim que é algo muito mais complexo, pois implica o reconhecimento da adequação da ação à qualità de tempi. As "regras gerais" são oferecidas como possibilidades que precisam ser avaliadas em relação às circunstâncias concretas nas quais a ação se desenrola. Mesmo quando são apresentadas como "regras que nunca, ou raramente, falham", sua execução se mostra sempre passível de imprevistos capazes de anular sua eficácia, pois, como qualquer ação, implicam uma dose de risco ineliminável que põe em risco o êxito.

9 Conal Condren chega a dizer que, "salvo no sentido mais amplo, Maquiavel não pode ser chamado de filósofo, seja pelos padrões formais do seu tempo ou do nosso" (Condren, 1983, p. 94). Em apoio a essa afirmação, Condren argumenta: "ele nunca definiu; nunca empregou um vocabulário filosófico formal; tudo isso está expresso na sua famosa afirmação de que se achava interessado pela verdade efetiva das coisas" (Condren, 1983, p. 94). 
Essa ideia, de que Maquiavel tem em vista o estabelecimento de determinado conjunto de "regras gerais" da ação política, encontra apoio em diversas passagens de sua obra. Assim, por exemplo, lemos em "Discursos" I,9:5: "E deve-se tomar isto por uma regra geral: que nunca, ou raramente, acontece que alguma república ou reino seja em seu princípio bem ordenado ou reformado inteiramente com ordenações diferentes das antigas, se não é ordenado por um só" (grifos nossos). Também em "O Príncipe" 3:50: "Do que se extrai uma regra geral a qual nunca, ou raramente, falha: que aquele que faz alguém poderoso causa a sua ruína..." (grifos nossos). A questão é, obviamente, determinar como Maquiavel chega a essas "regras gerais" e quais funções desempenham no quadro de sua compreensão da ação política. ${ }^{10}$

Quanto a essa questão, Chabod, por exemplo, pondera que a observação da arte de escrever de Maquiavel nos revela uma constante no seu modo de analisar a ação política: de que o florentino extrairia os princípios gerais que a regem dos acontecimentos singulares da história passada e atual. Maquiavel, afirma ele, "salta de um só golpe" da experiência concreta, precisa, minuciosa até a "regra", vale dizer, explica ele, "que da observação particular ascende às normas gerais que regem, hoje como ontem, a ação política" (Chabod, 1994, pp. 288-289). A afirmação de Chabod precisa ser acolhida com certa precaução. Com efeito, quando examinamos a função exercida pelo exemplo no pensamento maquiaveliano, percebemos que a experiência histórica não é a "matéria-prima" a partir da qual Maquiavel extrai regras gerais da política. Os acontecimentos históricos não são a origem de regras, como defende Chabod, mas apenas a provocação à imaginação para explicá-los. Maquiavel não ascende dos acontecimentos históricos às regras gerais, mas antes destas descende àqueles: são as regras que regulam a vida política que servem para entender os acontecimentos e não esses o ponto de partida para a formulação daquelas. Para Maquiavel, portanto, o sentido não é extraído dos fatos, mas aplicado sobre esses. Quer dizer, os fatos "falam" a partir de um plano que sobre eles é imposto. Assim, os acontecimentos históricos adquirem importância na medida em que acrescentam ou diminuem, confirmam ou negam a plausibilidade da regra geral. Isso significa que não encontramos em Maquiavel uma contemplação

10 Poderíamos enriquecer a lista com inúmeras passagens com as menções de Maquiavel a regras gerais da política. Confiram-se ainda as seguintes entre aquelas que consideramos mais significativas. Da Arte da Guerra, Livro III: "porque está uma regra geral: que aquelas coisas as quais não se podem sustentar, é preciso que se dê saída...". "Da Arte da Guerra", Livro IV: "Sobre o que quero que tomeis esta regra geral que ao melhor remédio que pode usar contra um projeto do inimigo é fazer voluntariamente aquilo que ele planeja que tu farás pela força". "O Príncipe" 23:11: "Porque essa é uma regra geral que não falha jamais: que um príncipe que não é sábio por si mesmo não pode ser bem aconselhado [...]". 
isenta dos acontecimentos. A situação não é observada de modo neutro, mas sempre à luz de "regras", isto é, de regularidades ou uniformidades que, segundo Maquiavel, coordenam os acontecimentos históricos, e os exemplos aduzidos são cuidadosamente selecionados de acordo com sua utilidade para confirmar ou corroborar tais regras.

O que determina a obediência às regras gerais é a necessità, e compreender isto e adaptar seu agir a ela revela o grau de virtù do agente político. Ao derivar o caráter "forçoso" da ação política da exigência de êxito, Maquiavel revela que a obrigação de agir de determinado modo não é absoluta. A necessidade, para Maquiavel, aparece ao homem como um imperativo cuja natureza é política: deve-se agir ou deixar de agir de determinada forma, porque a ação política está condicionada pelo resultado. Toma, pois, a feição de um "princípio de ação", como explica Senellart (1989, p. 39):

[...] a necessidade se manifesta sob a forma de um perigo repentino ao qual se está coagido a fazer face para salvar sua vida. Ela é, portanto, ao mesmo tempo pontual e total. Maquiavel precisa, porém, que ela mesma dita aos homens a conduta a adotar, dispensando-os de qualquer reflexão.

A necessità é, assim, a coação imposta pelas condições reais nas quais a ação política se desenrola. Ao constranger os homens a seguir a única alternativa viável concretamente nas circunstâncias dadas, evita a dispersão a que a ação estaria sujeita se resultasse da escolha. ${ }^{11}$ Podemos notar, pois, que o objetivo de Maquiavel é oferecer elementos que ajudem a executar a ação que proporcione o êxito. No entanto, ele não pretende realizá-lo apresentando alternativas de êxito seguras. Muito pelo contrário, Maquiavel pretende que cada qual busque por si mesmo as condições de sucesso da ação a partir do contexto concreto em que se encontra. Isto, porém, não significa que o florentino deixe de oferecer indicações, como mostramos acima, na forma de "regras gerais" da ação política. Essas não são respostas prontas e universalmente válidas, mas referências gerais a partir das quais o agente político poderá conceber sua ação com uma margem de segurança maior em relação ao resultado.

11 Em muitas passagens de sua obra Maquiavel menciona a elezione como fonte de ações afastadas da vera via ou do perfetto e vero fine. Assim, podemos ler em "Discursos" I,1:14: "E porque os homens agem ou por necessidade ou por elezione e porque se vê existir maior virtù onde a elezione tem menos autoridade [...]"; "Discursos" I, 3:5 : "[...] mas onde a elezione abunda e se pode usar de licença, tudo logo se enche de confusão e desordem"; "Príncipe" 13:4: "[...] mas a sua boa fortuna fez nascer um terceiro fator, a fim de que não colhesse o fruto de sua mala elezione". 


\section{d) Necessità como força histórica}

Maquiavel não reconhece a existência de forças transcendentes, como a Providência ou os astros, com poder de determinar as ações humanas: nenhuma transcendência determinando as ações pode ser invocada para subtrair o homem à sua responsabilidade. Apesar disso, determinadas configurações históricas apresentam ao homem uma situação que "clama" pela intervenção. Esse tipo de necessidade indica as forças presentes e atuantes nessas situações, as quais oferecem ao homem de virtù uma oportunidade singular de intervenção na história.

Em "O Príncipe" Maquiavel menciona ao menos três exemplos que ilustram esse significado de necessidade. Assim, escreve Maquiavel, "era necessário a Moisés encontrar o povo de Israel no Egito escravo e oprimido pelos egípcios, a fim de que aquele se dispusesse a segui-lo" ("Príncipe" 6:11 - grifos nossos). A mesma necessidade como condição da ação é referida para os feitos dos demais grandes fundadores (Rômulo, Ciro e Teseu). No capítulo seguinte, Maquiavel refere, em relação à obra de César Borgia, o domínio da mesma necessidade: "era, portanto, necessário perturbar aquelas ordens e desordenar os estados da Itália, para poder assenhorear-se seguramente de parte deles" ("Príncipe" 7:13 - grifos nossos). Finalmente, no capítulo conclusivo da obra, associa a necessidade de fundar um Estado italiano à mesma necessidade que levou à fundação mosaica, de Rômulo, Ciro e Teseu mencionados no capítulo VI:

[...] assim, no presente, desejando-se conhecer a virtù de um espírito italiano, era necessário que a Itália se reduzisse a seu estado atual, e que ela fosse mais escrava que os hebreus, mais serva que os persas, mais dispersa que os atenienses: sem chefe, sem ordem, abatida, espoliada, dilacerada, invadida, e tivesse suportado toda sorte de ruína ("Príncipe" 26:3 - grifos nossos).

A necessidade coincide aqui com a occasione sem a qual a ação fundadora não seria possível. Maquiavel mostra, nas passagens transcritas, que o êxito da ação depende de uma circunstância contingente, de algo impossível de ser produzido pela virtù humana. A "ocasião" é esse momento único que abre à ação humana a possibilidade da criação histórica. Nesse sentido, a ocasião possibilita à virtù mostrar-se. A virtù precisa se manifestar para existir, uma vez que é uma atividade: uma virtù implícita, passiva, seria uma contradição lógica. É preciso, pois, para que a virtù exista que ela encontre o meio de inscrever-se no real. A ocasião é esse meio: uma brecha na necessidade que possibilita a ação histórica. Quando Maquiavel insiste em que sem essa ocasião nada teria acontecido, por maior que pudesse ser a virtù dos homens, mostra sua inelutável vinculação à necessidade. Somente sob aquelas circunstâncias a ação humana poderia ser levada a efeito com êxito. Aqui, pois, necessidade não é uma constrição externa 
ou interna que impõe ao homem uma ação determinada, e sim um espaço de possibilidade para a ação criadora na história. Aqui a necessidade não obriga; ela possibilita; ou seja, a ocasião não é nada mais do que a oportunidade da ação e a liberdade humana se confunde com nossa capacidade de arriscar-nos na ação para dar um sentido ao futuro.

\section{e) Necessità como constrição legal}

A necessidade nessa acepção relaciona a lei a uma segunda natureza: assim como a necessidade natural coage os homens a agir de um determinado modo, a lei civil produz o mesmo efeito: "os homens nunca fazem bem algum, a não ser por necessidade; mas onde a escolha abunda e se pode usar da licença, tudo logo se enche de confusão e desordem. Por isso se diz que a fome e a pobreza tornam os homens industriosos, e que as leis os tornam bons" ("Discursos" I,3:5-6 - grifos nossos). O sentido aqui pretendido com a expressão "as leis os tornam bons" é o de indicar que a lei força ou obriga, o que retira a qualidade voluntária, ou subjetivamente moral, do termo "bons". "Bons" refere-se aqui a um bem medido pela conformidade dos atos ao critério promulgado pelas leis. Por essa interpretação, os homens se conformam à norma legal não porque reconhecem nela um valor, mas em consequência da coação externa produzida pela força.

A capacidade de produzir pela lei uma necessidade equivalente a da natureza é destacada por Maquiavel na descrição da fundação das cidades. Maquiavel começa sua análise ponderando que, "como se vê que existe maior virtù onde a escolha tem menos autoridade", parece preferível edificar as cidades em lugares estéreis para que a natureza se encarregue de obrigar os homens "a esforçar-se e a ocupar-se menos com o ócio" ("Discursos" I,1:14), vivendo unidos por terem menos motivos, devido à pobreza do lugar, de desunião. Essa escolha seria a mais sensata e a mais útil, se os homens se contentassem em viver com o que têm e não quisessem comandar os outros. Mas, uma vez que "só o poder dá segurança aos homens", é necessário evitar tal esterilidade e viver em lugares muito férteis. O que parecia ser uma escolha livre fica restrito a uma escolha entre necessidades e decidida pela necessidade soberana: o desejo dos homens de comandar outros homens. ${ }^{12}$

12 Aqui é preciso esclarecer que o "desejo de comandar outros homens" não é algo que "todos" os homens realizam, mas somente aqueles que se situam na posição espacial de comando, ou seja, os "grandes". Aqueles que estão no polo oposto, isto é, em vez de "comandar" são "comandados", são "povo". Assim, ainda que do ponto de vista da natureza humana exista um desejo universal de comandar outros homens, na forma como os homens se distribuem no espaço político apenas uma parte deles (os grandes) é animado por esse desejo. 
Uma vez resolvida a questão da "escolha", Maquiavel se move para a questão seguinte: como evitar o ozio em uma cidade fundada em lugar fértil. A segunda preocupação do legislador decorre da primeira: para evitar o ócio, "devem-se criar ordenações para que as leis obriguem [os homens] a tais necessidades que o lugar não obriga" ("Discursos" I,1:16). As leis devem reproduzir a restrição da necessidade ou esterilidade do lugar. São uma espécie de "necessidade artificial" inventada para substituir a "necessidade natural" quando essa falta. Elas permitem que os homens tirem proveito da fertilidade natural, que de outra forma tornaria os homens preguiçosos. Sem leis, os homens são inseguros ou por causa de sua pobreza ou por causa do ócio.

É preciso esclarecer que Maquiavel não dissolve tudo na coação legal operada pela força. Muito embora seja verdade que, em geral, os homens "nunca anuem a uma lei nova que tenha em vista uma nova ordem na cidade, a não ser que lhes seja mostrado, por alguma necessidade, que é preciso fazê-lo" ("Discursos" I,2:8), a pura necessidade produzida pela força da coação não é suficiente. Com efeito, "assim como os bons costumes precisam das leis para manter-se, também as leis, para serem observadas, precisam de bons costumes" ("Discursos" I,18:5). Leis e bons costumes se movem em uma circularidade virtuosa. Os bons costumes internalizam o valor de seguir a lei e alcançam seu cumprimento sem o emprego ostensivo da força.

Para que as leggi produzam o efeito de uma "necessidade artificial" é preciso que cumpram com uma dupla exigência. Primeiro, Maquiavel usa a palavra leggi para restrições artificiais que adquirem autoridade por meio do consentimento de quem vive sob elas. Não há dúvida de que a força "necessária" das leis é apoiada pela força física, mas a própria força é estritamente regulada pela autoridade pública. Leis aplicadas na ausência de tal autoridade dependem da força bruta ou fortuna efêmera de governantes individuais, e não podem produzir ordens virtuosas de forma estável. Segundo, leis para Maquiavel, são sempre produto da atividade de ordenação humana. Por isso, sequer as regularidades mais "naturais e normais" ou "comuns e razoáveis" da conduta humana são tomadas por Maquiavel como evidências a partir das quais leis naturais prescritivas poderiam ser derivadas. Para Maquiavel, as leis autoimpostas são as únicas leis prescritivas válidas conhecidas pelos homens.

\section{Considerações finais}

Maquiavel fala em "Discursos" (II,8:22) em ultima necessità, isto é, em "necessidade extrema" ou "necessidade fundamental", para referir-se à situação na qual "povos inteiros, impelidos pela necessidade", são forçados a deixar suas 
casas e a "procurar novas terras [...] entrando com violência nas províncias alheias, matando seus habitantes, tomando posse de seus bens, criando um novo reino e mudando o nome do lugar" ("Discursos", II,8:16-17). A mesma expressão ultima necessità reaparece em "História de Florença" quando um orador exorta os seus compatriotas para a guerra com as palavras: "há uma necessidade fundamental que deve fazer-nos obstinados na defesa". O mesmo orador, um dos cidadãos "mais velhos e sábios" da cidade, ainda declara que "as coisas feitas por necessidade não devem nem podem merecer elogios ou censura" ("História de Florença" V,11). As passagens tomadas fora de seu contexto poderiam levar-nos a pensar que existiria para Maquiavel um necessitarismo, ou um determinismo inelutável. Não é isso, porém, o que Maquiavel sugere. Mesmo sob constrições extremas - sob ultima necessità - os agentes estão postos em situação de escolha e, por isso, são responsáveis por elas. No mínimo, retomando aqui o argumento de Erica Benner (2009, p. 146), "podem optar por fugir ou por ficar e lutar. E então devem escolher a forma de fugir ou de lutar”. Uma vez que essas opções estão sempre disponíveis, mesmo sob uma "necessidade fundamental", há sempre espaço para o louvor e a crítica.

A ação humana, portanto, jamais se desenvolve no vazio. Ela sobrevém, sobretudo, no âmbito de um processo já em curso, de um sistema de forças ativas direcionadas a um fim determinado: à criação ou conservação de uma ordem. Superar a resistência das coisas significa apossar-se da sua racionalidade interna para obrigá-las ao efeito desejado. Substitui, como diz Maquiavel, a natureza pelo engenho (l'industria), a virtù da necessidade pela necessidade da virtù, para fazer com que, posteriormente, l'industria e virtù se transformem, por sua vez, em necessidade e natureza e atuem com a mesma decisiva objetividade. Isso, porém, não significa que Maquiavel ofereça regras infalíveis para o êxito da ação política. As diferentes formas de necessidade por ele caracterizadas constituem um conjunto de regras prudenciais que o homem de ação precisa ter em conta, mas de forma alguma lhe asseguram o êxito sem margem de erro.

Em suma, nos diferentes usos do termo necessità Maquiavel não considera a ação humana como determinada de maneira definitiva por forças que inibem a liberdade. Pelo contrário, insiste em que a elezione está aberta ao homem mesmo naquelas situações nas quais segui-la o levaria ao fracasso. O que Maquiavel sugere é como colher a necessità própria aos tempos conservando o libero arbitrio que torna o homem responsável único pela ação histórica. Finalmente, ainda que a história apresente ao homem regularidades, leis estáveis que subtendem ao curso natural das coisas e regulam seu andamento - espécie de "regras gerais" - essas não se oferecem a ele como receitas prontas. Cada situação é única e a ação precisa ajustar-se sempre à qualità de 'tempi. Captar 
a necessità que subjaz aos acontecimentos eleva aquele que detém essa virtù a uma posição de vantagem em relação aos que não se mostram capazes disso. Enfim, podemos concluir com Raimondi (2009, p. 50): "só ocupando-se em pensar a conquista da liberdade no próprio tempo Maquiavel consegue expor uma lei verdadeiramente universal, que diz aos homens 'usufruí, portanto, o bem e o mal que vós mesmos desejastes" ("Discursos", Dedicatória:11).

\section{Referências}

BENNER, E. "Machiavelli’s Ethics". Princeton: Princeton University Press, 2009.

CHABOD, F. "Escritos sobre Maquiavelo". Tradução de Rodrigo Ruza. $2^{\mathrm{a}}$ ed. México: Fondo de Cultura Económica, 1994.

COLLONA D’ISTRIA, G., FRAPET, R. “L'Art polique chez Machiavel”. Paris: Vrin, 1980 .

CONDREN, C. "Marsílio e Maquiavel”. In: FITZGERALD, R. (org.). Pensadores Políticos Comparados. Brasília: EdUnB, 1983.

DE GRAZIA, S. "Maquiavel no inferno". São Paulo: Companhia das Letras, 1993.

GILBERT, F. "Machivelli e Guicciardini: Pensiero politico e storiografia a Firenze nel Cinquecento". Torino: Einaudi:1970.

. "Machiavelli e il suo tempo". Bologna:Il Mulino, 1977.

KERSTING, W. "Handlungsmächtigkeit - Machiavellis Lehre vom politischen Handeln". Philosophisches Jahrbuch, Vol. 95, Nr. 2, pp. 235-255, 1988.

MACHIAVELLI, N. "Discorsi sopra la prima Deca di Tito Livio". Introdução de Gennaro Sasso; preâmbulo e notas de Giorgio Inglese. Milano: Rizzoli Editore, 2000. MACHIAVELLI, Niccolò. Lettere. In: Tutte le Opere: a cura di Mario Martelli. Firenze: Sansoni, 1992. p. 1007-1256.

MAQUIAVEL, N. "O Príncipe" (edição bilíngue). Tradução e notas de José Antônio Martins. São Paulo: Hedra, 2009.

MEINECKE, F. "Die idee der Staatsräson in der neueren Geschichte”. München/Berlin: R. Oldendbourg, 3, durchgesehene Auflage, 1929.

MOSSINI, L. "Necessità e legge nell'opera del Machiavelli". Milano: Dott. A. Giuffrè Editore, 1962.

RAIMONDI, F. “'Necessità' nel Principe e nei Discorsi di Machiavelli”. Scienza \& Politica, Nr. 40, 2009.

SÁNCHEZ-PARGA, J. "Poder y política en Maquiavelo". Rosário: Homo Sapiens Ediciones, 2005.

SENELLART, M. "Machiavélisme et raison d'État". Paris: PUF, 1989.

VON MURALT, L. "Machiavellis Staatsgedanke”. Basel: Benno Schwabe \& Co., 1945. 